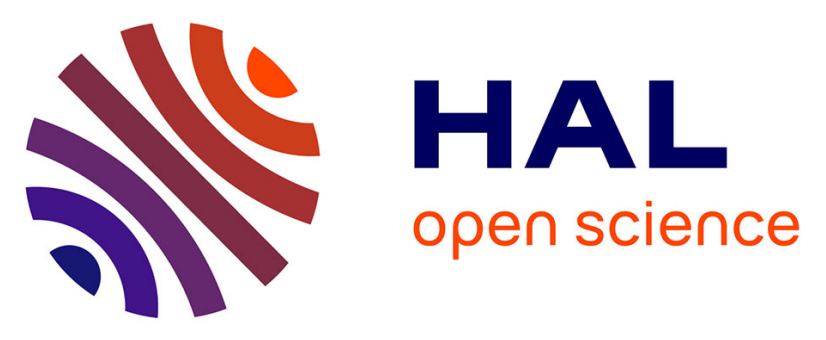

\title{
Cryoturbation versus tectonic deformation along the southern edge of the Tunka Basin (Baikal Rift System), Siberia: New insights from an integrated morphotectonic and stratigraphic study
}

Anastasia Arzhannikova, J.F. Ritz, Christophe Larroque, Pierre Antoine, Sergey Arzhannikov, Aleksei Chebotarev, Jean-François Stéphan, Marc M. Massault, Jean-Luc Michelot

\section{- To cite this version:}

Anastasia Arzhannikova, J.F. Ritz, Christophe Larroque, Pierre Antoine, Sergey Arzhannikov, et al.. Cryoturbation versus tectonic deformation along the southern edge of the Tunka Basin (Baikal Rift System), Siberia: New insights from an integrated morphotectonic and stratigraphic study. Journal of Asian Earth Sciences, 2020, 204, pp.104569. 10.1016/j.jseaes.2020.104569 . hal-03089609

\section{HAL Id: hal-03089609 \\ https://cnrs.hal.science/hal-03089609}

Submitted on 4 Jan 2021

HAL is a multi-disciplinary open access archive for the deposit and dissemination of scientific research documents, whether they are published or not. The documents may come from teaching and research institutions in France or abroad, or from public or private research centers.
L'archive ouverte pluridisciplinaire HAL, est destinée au dépôt et à la diffusion de documents scientifiques de niveau recherche, publiés ou non, émanant des établissements d'enseignement et de recherche français ou étrangers, des laboratoires publics ou privés. 
4

Anastasia Arzhannikova ${ }^{1 *}$, Jean-François Ritz ${ }^{2}$, Christophe Larroque ${ }^{3}$, Pierre Antoine ${ }^{4}$,

6 Sergey Arzhannikov ${ }^{1}$, Aleksei Chebotarev ${ }^{1}$, Jean-François Stéphan ${ }^{3} \dagger$, Marc Massault M. ${ }^{5}$,

7 Jean-Luc Michelot ${ }^{5}$

8 1: Institute of the Earth’s Crust, Russian Academy of Sciences, Siberian Branch, Irkutsk,

9 Russia

2: Geosciences Montpellier Laboratory, CNRS, University of Montpellier, Montpellier,

11 France

12 3: Geoazur Laboratory, University Côte d'Azur, Observatoire de la Côte d'Azur, CNRS, IRD,

13 Valbonne, France

14 4: Laboratory of Physical Geography, Quaternary and Present Environments, CNRS, 15 University of Paris 1 \& UPEC, Meudon, France

16 5: Laboratory GEOPS, CNRS, University of Paris-Sud, CNRS, University of Paris-Saclay, 17 Orsay, France

* Corresponding authors

20 Anastasia Arzhannikova

21 e-mail: arzhan@crust.irk.ru

22 Jean-Francois Ritz (ORCID 0000-0002-7351-8877)

23 Email: jean-francois.ritz@gm.univ-montp2.fr 
AbstractThe Tunka Basin is a broad, emerging basin situated between the Baikal Lake to the east and the the Hövsgöl Lake to the west. The basin is bounded to the north and to the south by the Tunka and the Khamar-Daban mountain ranges, respectively. The Tunka normal fault, located at the southern foothills of the Tunka mountain range, is the main structure that controlled the development of the Tunka Basin during the Neogene. Paleoearthquake-surface ruptures attest of its present activity; and show that its western and eastern terminations are undergoing a tectonic inversion characterized by left-lateral-reverse deformations. The southern edge of the Tunka Basin is classically interpreted as being tectonically controlled. In this paper, we present the results of a geomorphological and stratigraphic analysis within its southwestern and southeastern parts suggesting that there is no active fault affecting the foothills of the Khamar-Daban mountain range. The different features observed in the Quaternary deposits are interpreted to be the result of periglacial processes induced by alternating episodes of permafrost aggradation and degradation during the Holocene. Our study concludes that the Khamar-Daban Range and the Tunka Basin are uplifting together, and that the Tunka and Mondy faults are the two main triggers of regional earthquakes.

Keywords: Baikal Rift System, Tunnka Basin, Quaternary deposits, morphological and stratigraphic analyses, periglacial processes, cryoturbation

\section{Introduction}

The Tunka Basin is located in the southwestern part of the Baikal Rift System. As many of the Baikal Rift basins, it shows a morphological asymmetry characterized by a sharp and steep border on the northern side, and a smooth morphology on the southern one (Logatchev, 1974; 2003). To the North, the south-dipping Tunka normal fault, located at the foothills of the Tunka mountain range (Fig. 1), corresponds to the main structure that controlled the 
development of the Tunka Basin (Sherman et al., 1973). Along this fault, Quaternary landforms and sediments are affected by paleoearthquake surface ruptures attesting of its present activity (e.g. Khromovskikh et al., 1975; McCalpin and Khromovskikh, 1995; Chipizubov et al., 2003; Smekalin, 2008; Smekalin et al., 2013; Ritz et al., 2018; Arzhannikova et al., 2018).

Regarding the southern edge of the Tunka Basin, the question of a tectonic control with a south Tunka fault located at the foothills of the Khamar-Daban mountain range (Fig.1), presently active, remains a major question notably in terms of seismic hazard. Several studies propose the occurrence of one or several active faults (e.g. Sherman et al., 1973; Lukina, 1989; Lunina and Gladkov, 2004), potentially the source of large historical earthquakes (Lukina, 1989, Radziminovich and Shchetnikov, 2013). However, there are no clear morphotectonic and/or paleoseismological observations attesting to those structures.

During the last glacial period, the late Quaternary sediments of the Tunka Basin are affected by intense and widespread cryoturbation processes due to the periglacial environment close to large mountain ice caps (Alexeev et al., 2014). These processes have induced surficial deformation that has been interpreted as seismites (Glagkov and Lunina, 2010). In such environments, the question of distinguishing deformations caused by tectonic processes from those induced by periglacial processes is a major concern (e.g. Audemard and de Santis, 1991; Mc Calpin, 1996; Van Vliet-Lanoe et al., 2004; Obermeier et al., 2005; Baize et al., 2007).

In this paper, we present the results of a detailed morphotectonic and stratigraphic analysis along the southern edge of the Tunka Basin. Our observations allow: 1) describing several features of particular relevance for discussing their origin (i.e. seismogenic vs cryogenic origin); and 2) discussing whether or not there is an active fault bounding the Tunka Basin to the south. Our results have implications about the recent geodynamic evolution of the Tunka Rift, and the regional seismic hazard. 


\section{Tectonic setting}

78

The Tunka Basin is a broad E-W trending emerged basin (200 km long, 10-30 km wide), connecting the Baikal Basin to the NE in Russia, and the Hövsgöl Basin to the SW in Mongolia. Along with the other basins of the Baikal Rift System, the Tunka Basin defines the northwestern border between the Amurian Plate and the Siberian Craton (Petit and Fournier, 2005; Petit and Déverchère, 2006). The Tunka Basin is bounded by the Tunka and KhamarDaban mountain ranges to the north and the south, respectively. These ranges differ in their geomorphological characteristics. The Tunka Range shows alpine-type reliefs with narrow ridges and peaks incised by glacial cirques and valleys. The highest summits reach more than $3000 \mathrm{~m}$ asl, and are located less than $10 \mathrm{~km}$ from the southern foothills. The reliefs in the Khamar-Daban Range are smooth and present summit plateaus which an altitude of 500 to 700 m lower than the Tunka summits. The northern slope of the Khamar-Daban Range dips gently to the Tunka Basin, with highest reliefs 20-25 km southwards from the foothills.

The Tunka Basin shows a complex inner structure with smaller depressions (from west to east: Mondy, Khoytogol, Turan, Tunka sensus stricto and Tory) separated by interbasin highs (Nilovsky and Elovsky spurs) (Fig. 1b). These depressions differ in size and depth of basement, with the greatest depths situated northward against the Tunka Fault (Sherman et al., 1973). The Tunka depression, located in the centre of the Tunka Basin, is the largest in size and sediments thickness. The mean topographic surface of the Tunka Basin dips towards the east from $1350 \mathrm{~m}$ asl to $650 \mathrm{~m}$ asl, and then shows a $700 \mathrm{~m}$ difference of height over the 170 km length of the basin (Fig. 1b).

The Tunka Basin is filled with Oligocene to Quaternary deposits up to $3 \mathrm{~km}$ thick. The drilling data show that the lower part corresponds to Oligocene-early Pliocene fine-grained volcano-sedimentary rocks, while the upper part corresponds to late Pliocene- 
101 Quaternary coarse-grained sediments (Sherman et al., 1973; Mazilov et al., 1993). This difference in sedimentation has been interpreted as markers of a slow then fast stages in the rifting process (e.g. Logatchev and Zorin, 1987; Mats et al., 2001; Krivonogov and Safonova, 2017). The late Pleistocene-Holocene formations are mainly composed of fluvio-glacial and alluvial deposits (boulder-pebbles, gravels, sands) and aeolian sediments (silts, loess) (Ravsky et al., 1964; Shchetnikov et al., 2012). Most of the coarse-grained material is accumulated within the Tunka Range piedmont, while the fine-grained sediments are drifted to the inner parts of the depressions. The lower areas are covered by numerous lakes and swamps due to a shallow permafrost that can be up to hundreds of meters thick (Logatchev, 1974). The Tunka Basin and the Tunka Range still show features associated with the Late Pleistocene glaciation such as glacial valleys, cirques, moraines and kame terraces. During the last glaciation, a 300 m thick glacier occupied the westernmost part of the Tunka Basin (i.e. Mondy Valley) 113 (Olyunin, 1965). In situ-produced ${ }^{10}$ Be dating of Mondy terminal-moraine yielded an average exposure age of 14 ka (Arzhannikov et al., 2015). During the last glaciation, an intense aeolian activity occurred and was associated with the deposition of loess, sandy loess and the

116 formation of sand dunes and ridge-and-runnel topographic features (Ravsky et al., 1964).

117 According to Shchetnikov et al. (2012), the maximum period of aeolian sedimentation in the 118 Tunka rift basin occurred at the end of the Late Pleistocene and during the Early Holocene. Cryogenic deformations such as ice wedges and other cryoturbation features were observed in the cross sections within the Upper Holocene alluvial sediments (Alexeev et al., 121 2014). Solifluction phenomena due to thawing permafrost are commonly observed in the 122 superficial deposits (Ravsky et al., 1964). Nowadays, the Tunka Basin corresponds to an emerged rift structure. It is located

124 within a transition zone between the present-day compressional deformation of North 125 Mongolia and the extensional one of the central Baikal Rift as attested by the focal 
mechanisms of earthquakes (Melnikova and Radziminovich, 1998; Radziminovich et al., 2016). Morphotectonic and paleoseismic analyses show that the kinematics of faults controlling the Tunka Basin changed through time. From the Miocene to the Quaternary a transtensional regime dominated, with normal and left-lateral strike-slip faulting along the major fault zones, allowing the opening of basins and thick accumulation of loose sediments (San'kov et al., 1997). Then the strain regime was replaced by a transpressional regime in the Late Quaternary combining compressional and left-lateral strike-slip fault deformations (Larroque et al., 2001; Arzhannikova et al., 2005; Arjannikova et al., 2004; Arzhannikova, Melnikova, Radziminovich, 2007; Jolivet et al., 2013; Ritz et al., 2018). This recent transpressional strain regime would be the result of the northwards propagation of the collisional deformation associated with the convergence between India and Asia (Ritz et al., 2000). Evidence of recent inversion was observed along the Mondy Fault and its western extension northward of the Hövsgöl Lake (Larroque et al., 2001; Arzhannikova et al., 2003; Arjannikova et al., 2004) and along the East Tunka Fault and East Sayan Fault (Chipizubov et al., 2003; Smekalin, 2008; Shchetnikov, 2016; Ritz et al., 2018; Arzhannikov et al., 2018).

The question of an active fault located at the southern edge of the Tunka Basin remains undetermined. From geomorphological and structural considerations Sherman (1973) has proposed a fault bounding the Turan and Tunka depressions to the south at the foothills of Khamar-Daban Range (Fig. 1b). Lukina (1989) and Lunina and Gladkov (2004) extended this fault until the Baikal Lake. However, no evidence of deformations in the Upper PleistoceneHolocene deposits has been described along this hypothetic structure. At the western end of the basin, evidences of tectonic scarps associated to the Mondy Fault are observed at the southern foothills of the Nilovsky Spur until its eastern limit (Geological map-East Sayan series, 1961; Arjannikova et al., 2004) (Fig. 1b). Moreover, two historical earthquakes were felt within this area in 1814 (Shimki Village, I=IX (MSK)) and in 1829 (Turan and Shimki 
151

152

153

154

155

156

157

158

159

160

161

162

163

164

165

166

167

168

169

170

171

172

173

174

175

villages I=VII-VIII, Mondy Village I=IX) (Kondorskaya and Shebalin, 1977) (Fig. 1a). After

Lukina (1989) and Radziminovich and Shchetnikov (2013), these historical events were produced by rupture of the western part of the South Tunka Fault or by the Mondy Fault.

Currently, the instrumental seismicity is much active in this western part than in the eastern part of the Tunka Basin (e.g. Solonenko et al., 1997; Radziminovich et al., 2013) (Fig. 1a). Among these instrumental earthquakes two events of magnitudes M4.5 and M5 occurred near Kyren Village in 1958 (Golenetsky, 1998).

\section{Methods}

In our study, we used morphotectonic and stratigraphic analyses. Morphotectonic analyses were based at first on a remote sensing study of Google Earth satellite images, aerial photographs and TanDEM-X digital elevation models with resolution of $12 \mathrm{~m} / \mathrm{pixel}$, of the foothills of the Khamar-Daban Range to determine whether or not there is an active fault along the southern margin of the Tunka Basin. These remote sensing analyses were then completed by field investigations within locations where the occurrence of morphotectonic markers were in question. Those included the detailed analysis of the topography and the morphology of the markers, as well as the analysis of the stratigraphy of deposits and their potential deformations through trenches studies. Age constraints of stratigraphic units were provided by the radiocarbon dating of samples containing organic matter. The radiocarbon samples were analyzed at the French National Platform LMC14 of the National Service of INSU “ARTEMIS”. Dendrochronologically calibrated calendar age ranges were calculated using the program Calib 7.1 Radiocarbon Calibration (Stuiver et al., 2019) with 2 standard deviations uncertainty. The age ranges are rounded off to the nearest decade.

\section{Geomorphology, Quaternary sediments and structures}




\subsubsection{Geomorphology of the Kyren area}

178 The area studied near Kyren is located within the central part of the Tunka Basin at the

179 foothills of the Khamar-Daban Range (Fig. 2). Contrary to what is observed along the Tunka

180 Fault, bounding the basin to the north, this southern boundary corresponds to a smooth slope

181 comprised between 800 and $900 \mathrm{~m}$ in altitude. Topographic profiles performed across this

182

183

184

185

186

187

188

189

190

191

192

193

194

195 morphological feature do not show evidence of scarp, but instead a smooth regular convex profile (Fig. 2d, profile 1). Assuming that a possible fault was running along this inflexion line, we carefully analysed the morphology of the three largest alluvial fans at the outlets of the Haragun, Haribiati and Algak-Kyren rivers, searching for a recent fault scarp. Detailed field observation of the outlet areas did not reveal any abnormal topographic variation, as shown by profiles 2 and 3 (Fig. 2d). Moreover, we did not observe uplifted or even clearly stepped fluvial terraces within the drainage network inside the Khamar-Daban Range. On the contrary, the longitudinal incision profiles of the various rivers are continuous throughout the different sedimentary depressions in the Tunka Basin.

However, on an aerial picture, we have been puzzled by an E-W linear feature affecting the Holocene deposits forming the plain at the east of the right bank of the Algak River, to the south of Kyren Village (Fig. 3a, see Fig. 2a for location). In a satellite image, this feature is much less obvious, and seems to underline the northern edge of a ridge-andrunnel topography area (Fig. 3b). The satellite image also allowed pointing out some smaller W-E aligned “dome structures” (Figure 3b). To decipher whether these structures are tectonic features and could correspond to the hypothetic south Tunka fault or not, we carried out field works including trenching throughout the W-E aligned break in the slope profile and two “dome structures”. These investigations where completed by the study of the sedimentary 
200

201

202

203

204

205

206

207

208

209

210

211

212

213

214

215

216

217

218

219

220

221

222

223

224

section located on the right bank of the Algak River (Figure 3b), where fluvial erosion has produced a $6 \mathrm{~m}$ high sub-vertical cliff in a meander concavity.

\subsection{2- Stratigraphy of Quaternary deposits: the Algak River bank section}

From the base to the top, the Algak River bank section exposes fluvial, then fluvio-aeolian and aeolian deposits affected by a thick deformation horizon in their upper $1.5 \mathrm{~m}$ (Fig. 4).

From the base to the top, the Algak River profile can be subdivided into three sub-sequences (SS1 to SS3) overlying the uppermost part of a peat layer occurring at -6.1 $\mathrm{m}$ at the level of the present day River (Fig. 4):

1) SS1 sub-sequence (-6.10 to $-4.8 \mathrm{~m}$ ) is first made by finely laminated greyish sandy to silty deposits corresponding to fluvial overbank deposits including thin organic debris layers. In the upper two third the sedimentation becomes more and more organic, two peat layers occur, and numerous well-preserved wood pieces, trunk remains, and even some in situ tree stumps are observed. Radiocarbon ages obtained from two wood samples show that this subsequence starts at the end of the Late glacial and that the tree stump horizon, associated with the uppermost peat layer, dates from the Early Holocene (Preboreal). Some involutions within unit 15 can be related to syngenetic freeze-thaw processes (deep seasonal frost) but no permafrost related features have been observed in the sediments deposited during this period. Without any palynological analysis it is difficult to describe more precisely the landscape but the large size of the wood remains and tree stumps recovered in this unit $(>20 \mathrm{~cm}$ in diameter) seems to indicate a forested taiga environment, at least developed in the alluvial plain, as described by Groisman et al. (2013) reporting the occurrence of "spruce and larch forests along the rivers”.

2) SS2 sub-sequence $(-4.8$ to $-1.5 \mathrm{~m})$ is made by three metres of laminated sandy silts including a thin (10 cm thick) dark grey organic layer (marshy soil, unit 9) and some thin 
syngenetic frost cracks at the base in unit 10 (depth: 0.2-0.3 m). Organic debris is still present but definitely less abundant compared to SS1. This part of the sequence results from a period of reactivation of fluvial activity in a more open (and colder?) environment in which aeolian processes are more and more intense to the top. By reference to the synthesis of Groisman et al. (2013) on the Holocene climate and environments in Siberia, deposits corresponding to the Boreal and Atlantic periods, and corresponding to the most forested period of the Holocene (until about $6000 \mathrm{BP}$ ), should be represented here by organic rich deposits including a lot of wood and tree remains. According to the facies of SS2, the Boreal and Atlantic periods are clearly lacking in the Algak River profile likely owing to the discontinuous character of fluvial sedimentation.

3) SS3 sub-sequence (- 1.5 to 0 ) is made by a succession of highly deformed beds of sandy silts and organic sandy silts layers (unit 5), then by homogeneous sandy deposits covered by a thin humic top soil horizon. This part of the sequence clearly shows the succession of at least two different events of aeolian sandy silt deposition alternating with episodes of intense deformation (load casting and diapiric features). According to the local climatic context (sporadic permafrost), these deformations are interpreted as cryoturbation features developed in the active layer of a permafrost by periglacial loading (Harris et al., 2000) or differential frost heave (Van Vliet Lanoë, 2004). Other outcrops observed along the banks of the Algak River show the large extension of this thick and complex deformation horizon in the Kyren area.

According to the study of Algak River bank section it is clear that no other periglacial horizon with large involutions is present below $1.5 \mathrm{~m}$ from the surface. This observation is in good accordance with another study made along the Irkut River banks where a thick layer of 1.5 to $2 \mathrm{~m}$ of highly deformed humic silts and sands associated with ice wedge pseudomorphs has been evidenced along several kilometres (Alexeev et al., 2014). In this study the cryoturbated 
250

organic rich layers located between - 40 and $-100 \mathrm{~cm}$ from the surface have been dated by radiocarbon analysis from 2600 and 3600 BP respectively (Alexeev et al., 2014). They correspond to a period of climatic instability starting with a very strong cooling event around 4500 BP followed by the alternation of several phases of climatic cooling and warming during the Subboreal (Groisman et al., 2013). According to the close correspondence between the thickness and the structure of the deformed layers in both the Upper part of the Irkut and Algak rivers banks sections it is proposed that the deformed layers of the Algak River profile in the Kyren area belong to the same period (Subboreal).

\subsection{3 - The ridge-and-runnel features}

4.1.3.1 MorphologyIn the flat area located to the East of the Algak River, and presently covered by steppe vegetation, the analysis of both Russian aerial photographs and satellite images allows evidencing numerous W-E elongated ridges (100 to $1000 \mathrm{~m}$ long) a few meters in high (Fig. 3b). They only occur in this area located to the East of the Algak River and not to the West in the alluvial plain between the Kyren and the Algak rivers. Features of the same type have also been observed further North, near Kyren Village (Fig. 3b), and are largely described in the Tunka Basin (Ravsky et al., 1964; Shchetnikov et al., 2012). They have been interpreted as resulting from aeolian deflation and transport by strong WE winds within the Tunka corridor (Shchetnikov et al., 2012).

This type of morphology is well known in the loess area of Central Europe where they are locally named “Greda” (Léger, 1990). They appear as for example along the right bank of the Danube River where they can reach more than $1 \mathrm{~km}$ long and $50 \mathrm{~m}$ high (Jipa, 2014). More recently the study of large Greda structures located in western Europe on the edge of the Odenwald plateau, connected to the right bank of the Rhine graben close to Heidelberg (Germany), evidenced the "onion peel” structure of the stratigraphic units making these 
elongated ridges (Antoine et al., 2001). They have been built by the rapid accumulation (14 m between about 30 and 17 ka (Moine et al., 2017)) of sands and silts deflated then transported as low level suspension from the braided alluvial plain of the Rhine during storms from NNW. These features, characterized by rapid accumulation of sandy loess showing laminated facies made by the alternation of sandy and silty layers up to $1 \mathrm{~cm}$ thick are typical of aeolian deposition in flat surfaces located immediately downwind of important sand and silt sources as braided periglacial rivers (Antoine et al., 2001). In the case of the Kyren area, the source of the silty material was the braided plain of the Irkut River located upwind of the ridge area and where active deflation processes occurred during the end of the Last glacial and the Younger Dryas, according to ${ }^{14} \mathrm{C}$ ages from trench 1 (see below) and in good agreement with the data published by Shchetnikov et al., (2012).

However, some of these small elongated domes (with length comprised between 10 and $25 \mathrm{~m}$ ) showing steep slopes, likely do not only result of pure aeolian processes. In order to understand the origin of these features we opened three trenches in the plain located at the east of the Algak River. Figure 5 shows the sites where they were opened: the first site (Fig. 5a) corresponds to an E-W smooth topographic scarp across which we opened trench 1 (Fig. 6). The second site (Figs. 5b and 5c) corresponds to E-W “oval dome structures”. There, we opened two trenches (Figs. 7 and 8, respectively).

\subsubsection{2 - Stratigraphy and deformations}

Within trench 1, we observed stratified (laminated?) silty-loess units and thin organic-rich paleosols affected by ductile deformations (Figs. 6a, b). In the southern part of the trench, the units are upturned along a 30-40 cm thick steeply dipping deformation zone delimited by highly deformed organic-rich horizons (dark brown silts). Within the upper part of the trench, just below the modern soil, the humic horizon bounding this deformation zone to the south, 
defines a $50 \mathrm{~cm}$ wedge (Fig. 6c). In the northern part of the trench, stratigraphic units are strongly folded and overturned towards the north. In some places, small brittle structures are associated with folding. A thin organic palaeosol horizon, interstratified within the deformed units, yielded an age between 11201 and 12078 calBP (Table 1), corresponding to the extreme end of the Younger Dryas or more likely to the very early Holocene, a period that is definitely more favourable to soil development (Groisman et al., 2013). We interpret the structure observed in the southern part of trench 1 as a deformed ice wedge pseudomorph characterized notably by the two highly crumpled humic horizons, which delimit it.

Figure 7 shows the features observed within trench 2 excavated across one of the small "dome structures” (see Fig. 3 for location). In this section, silty loess and silty-clayey units describe a knee fold with a steep flank towards the north. In front of the fold, stratigraphic unit are overturned as well as a humic palaeosol horizon that is sheared along a $\sim 30^{\circ}$ south-dipping ductile plane. Radiocarbon dating of a charcoal collected inside the sheared palaeosol yielded an age between 11204 and 11716 calBP (Table 1) indicating that the formation of this humic horizon must be allocated to the Early Holocene (Preboreal) as in trench 1 (Fig. 7b). At the back of the fold, where stratigraphic units are tilted southwards, we observe brittle structures (mainly small steep reverse faults) associated with folds. Another charcoal, collected from the beige silty unit just below the present soil horizon (30 $\mathrm{cm}$ depth), yielded a very young radiocarbon age of about 500 years calBP (Fig. 7a, Table 1). This age is likely not connected with the age of the sediment (translocation of a modern charcoal?).

A third trench was dug across another small dome structure (Fig. 8), in which silty to sandy loess units describe a symmetric $\sim 4 \mathrm{~m}$ wide isopaque anticline in the central part of the trench. On the southern flank of the fold, several steep north-dipping reverse faults affect the units (Fig. 8a). To the north and south of the anticline, units are overturned and sheared northwards and southwards downslope, respectively. Within the upper part of the trench, the 
above-described structures are eroded and then overlaid by a yellow silty horizon then by the organic horizon of the topsoil. A small trench (trench 3b, Fig. 9) dug perpendicularly to trench 3 (see location on the Fig. 3b) allowed analysing the features in 3D. The characteristics of the deformations exposed in trench 2, and the three-dimensional observations made at the intersection of the two profiles in trenches 3 and 3b (Figs $8 \&$ 9), have shown that the 330 deformation of the various sandy loess layers resulted from a slow and localised uplift 331 process. Some features are also produced by a slow collapse of the units (normal faults). According to the characteristics of the deformation and to the climatic context of the area during the Holocene (Groisman et al., 2013) we interpret the various “dome structures” and associated soft deformations as resulting from the growing of thick ice lenses a few meters

335 below the present day surface (not reached in the trenches). This type of features is extremely 336 common in areas located at the boundary between continuous and discontinuous permafrost 337 as today in Canada (Northwest Territories) and where mineral permafrost mounds or 338 cryogenic mounds (lithalsas, according to Harris, 1993) have developed during Late Holocene 339 in alluvial fine-grained sediments (Wolfe et al., 2014). In these environments, the 340 development of ice lenses within the soil (segregation ice lenses) is mainly linked to a flux of 341 unfrozen groundwater pumped by cryo-suction processes (Allard, et al., 1996; Pissart, 2002).

342 In the Kyren plain the formation of these permafrost mounds has led to the progressive 343 deformation and folding of the surficial periglacial sandy loess deposits. Brittle structures 344 observed on the flanks of the anticline are linked to episodes of growth when the entire 345 sedimentary cover was frozen, while the intensely sheared and overturned units observed on 346 both flanks of the fold correspond to solifluction features that formed during successive 347 thawing episodes. In trench 3, a thermokarst erosion feature showing sharp and irregular 348 erosion boundaries and a very heterogeneous infilling (including angular blocks of loess 349 transported as frozen blocks) results from the thawing of a former ice wedge (Fig. 9b, unit 4). 
This feature is a marker of a rapid event of permafrost degradation that could also be at the origin of the periglacial load casting processes observed in the uppermost part of the sequences exposed along the Algak River banks.

\subsection{Tuyana site}

The Tuyana site is situated at the junction zone between the Khamar-Daban Range and the Elovsky Spur at the eastern termination of the Tunka depression (Fig. 10 and Fig. 1 for location). There, the Irkut River incises the southern part of the Elovsky Spur over a length of $\sim 7 \mathrm{~km}$ before reaching the western termination of the Tory depression. As observed within the Kyren site, the southeastern edge of the Tunka depression with the Khamar-Daban Range defines a smooth and sinuous break of slope comprised between $750 \mathrm{~m}$ and $800 \mathrm{~m}$ in altitude. However, the 140 m deep incision of the Irkut River through the Elovsky Spur suggests that uplift is occurring in the area.

Figure 11 shows the TanDEM-X digital elevation model of the area where the Irkut River starts incising the Elovsky high. In this area, the DEM seems to define a 50 m width, $12 \mathrm{~m}$ deep, E-W linear gutter, affecting the foothills of a NS interfluve of Khamar-Daban Range northern flank (Figs. 11a, b).

Located in the western part of this area, the archaeological excavation of the Tuyana Upper Palaeolithic site (Kozyrev et al., 2014; Shchetnikov et al., 2019) (Fig. 11c) represents an important observation window. At that place the thickest sedimentary sequences (up to 4 $\mathrm{m})$ are located in depressions, whereas minimum thickness $(\leq 1 \mathrm{~m})$ is typical for the most elevated parts of the topography. All the stratigraphic profiles exposed by the archaeological excavation of the Tuyana site $\left(10000 \mathrm{~m}^{2}\right)$ were investigated to analyse the structures affecting the sediments. 
The profiles show a $3.5 \mathrm{~m}$ thick sequence composed by pale-yellow aeolian silts

375 (loess); laminated silty colluvial deposits and at least one thick dark brown humic palaeosol

376 horizon. The whole is overlying the weathered granitic bedrock. The sedimentation is

377 characterized by subaerial processes, under conditions of alternating humid and cryoarid

378 climates (Shchetnikov et al., 2019). Significant climate changes are recorded within the

379 sequence by the presence of buried soils and the widespread occurrence of cryogenic

380 deformations. The oldest deposits, including a buried palaeosol dated at about 36 ka calBP by

381 radiocarbon, belong to the Karga complex (Middle Pleniglacial / MIS 3) (Shchetnikov et al., 382 2019).

During field investigations cryogenic and gravitational deformations represented by cryoturbations, flow (gelifluxion) structures and associated fractures where identified. From the top of the sequence, the first cryogenic deformations are especially well exposed in the topsoil (Holocene) by load casting and diapiric features forming a continuous and widespread cryoturbation horizon (Shchetnikov et al., 2019) (Fig. 12 a,b). This cryoturbated horizon shows the same characteristics and has likely the same age than the one highlighted in the upper $1 \mathrm{~m}$ of the Algak River bank section in the Kyren area (see: 4.1.2). forming wedge-shaped structures filled with silty sediments. According to the radiocarbon ages published by Shchetnikov et al. (2019), a succession of several former ice wedge networks is recorded in the Tuyana sequence between the Karga period and the Holocene 394 (MIS 3 to 1) (Fig. 12b, c). At the very base of the sequence, the surface of the weathered 395 bedrock is locally penetrated by deformed ice wedge pseudomorphs and eroded by a system 396 of small channel-water streams (Fig. 12). We interpret these channels as the result of 397 thermokarst erosion following a rapid degradation of a former ice wedge network preceding 398 the deposition of the silty sediments. 

displacements such as landslides and mudflows associated with permafrost degradation events on slopes (Fig. 13). In the Tuyana sections, folded and lenticular structures as well as doubled or laterally beveled layers are widespread. Figure 13 (b,c) shows the deformations associated with the movement of large soil masses down slope inducing the formation of various folded structures and small cracks whose vertical extension is strictly limited to deformation 405 horizons.

Eventually, no tectonic faults crossing the deposits were observed in the various stratigraphic sections of the Tuyana Upper Pleistocene site where the whole deformation structures results from alternating phases of permafrost development and decay.

Figure 14 shows a 60-m long profile, subdivided in 6 sections, across the abovementioned E-W linear gutter observed in the DEM (see Fig. 11b for location). The sediments correspond to alternated carbonated loam, fine sandy loam and buried soils. The thickness of sediments is up to $1.2 \mathrm{~m}$ above the weathered granitic bedrock. From a nearby section, within the western part of the archaeological site, Shchetnikov et al. (2019) dated 2 buried soils, 414 which are 0.4 and $0.7 \mathrm{~m}$ deep, at 6310-6210 and 7720-7580 calBP, respectively. Thus, we 415 considered that the section shown in Figure 12 is Late Pleistocene-Holocene in age. 416 Liquefaction features are observed within the silty and organic-rich horizons. Small flame structures and folds can also be observed within the upper horizons, while larger flame structures with sometimes injection of weathered bedrock are observed in lower horizons.

As in Kyren, the features described above correspond to cryogenic structures and not 420 as tectonic ones. We therefore consider that the E-W linear feature observed on the DEM 421 (Fig. 11a, b) corresponds to an artefact due to the brutal change within the tree coverage. 422 After Google earth satellite imagery, this brutal change seems to be linked to an ancient tree 423 cutting band. 


\section{Discussion}

426 Our geomorphological and stratigraphic analysis of the Holocene soft-sedimentary deposits 427 and associated deformations along the southern edge of the Tunka Basin shows localised 428 features (ice wedge pseudomorphs) and large-scale horizons of periglacial deformations 429 (cryoturbations) resulting from alternating phases of permafrost aggradation and decrease 430 during the Holocene. Within both studied sites (Kyren and Tuyana), we did not observe any tectonic features as for instance a fault scarp that would run in front of the Khamar-Daban Range. On the contrary, the foothills of this range correspond to a smooth and sinuous break 433 of slope.

In Kyren site, morphotectonic and stratigraphic investigations show that the large scale 435 E-W trending ridge-and-runnel topography observed on the right bank of the Algak River at 436 the foothills of the Khamar-Daban Range corresponds to elongated aeolian ridges. These 437 features, known as "Greda” in the Central Europe loess zone are typical of aeolian sandy silt 438 deposition in periglacial environment close to braided river sources and have been described 439 in many other places elsewhere in the Tunka Basin (e.g. Ravsky et al, 1964). Their W-E 440 alignment is a marker of dominant palaeo-wind direction at the origin of deflation and transport of silts and sands during cold periods. We conclude that these morphologic features do not have a tectonic origin.

Besides, some remarkable elongated dome structures (between 10 and 25 m long)

444 locally occur in this Greda area. Parfeevets and San'kov (2006) interpreted these dome 445 structures as tectonic features, controlled by a NNE-SSW compression. They considered that 446 the loess units define an anticline structure, which was affected by brittle revere faults 447 (Parfeevets and San'kov, 2006). However, in the various trenches and cross sections 448 performed during our field works all the features observed can be related to the growing of 
segregation ice lenses producing upward deformation in the Late-glacial sandy silts of the area. The observed brittle deformation is simply due to the growing of the structure which generates internal contraction strength inside itself.

Finally, the $6 \mathrm{~m}$ high section described from the right bank of the Algak River shows that deformations and involutions are restricted to the upper $1.5-1.8 \mathrm{~m}$ of the sandy silts. The same type of structures resulting from the alternation of cold and warm events during the Subboreal have been described along several kilometres of the Irkut river banks by Alexeev et al. (2014). Although not directly dated, the ice wedge pseudomorph we observed in trench 1 strongly suggests the importance of cryogenic processes that appear widespread between the Kyren and Tuyana sites (Alexeev et al., 2014). In Tuyana site, similarly, we did not observe any indices suggesting the occurrence of active tectonic structures within the Upper Pleistocene-Holocene deposits. As within the Kyren site, the observed structures correspond to cryogenic features as the flame structures and folds that are associated with cryoturbation processes affecting the deposits during the Holocene, or the ice wedge pseudomorph affecting the Upper-Pleistocene deposits.

Therefore, our study strongly suggests that there is no evidence for active fault (i.e. South Tunka Fault) along the southern part of the Tunka Basin. This statement is attested by the fact that we observed neither horizontal displacement of channels nor uplifted fluvial terraces along the drainage network of the Khamar-Daban Range and its foothill. Indeed, the morphology and organisation of fluvial terraces systems represent a valuable marker reflecting recent vertical and horizontal tectonic motion. For example, slow uplift is necessary to build stepped terraces staircases whereas stability or relative subsidence produces thick stacked terraces (Antoine et al., 2000; Veldkamp et al., 2000; Bridgland et al., 2007).

On the contrary, we observe continuity and no abrupt change in the bedrock longitudinal profiles of rivers throughout the different sedimentary depressions in the Tunka 
474 Basin. Combined with the morphotectonic studies that demonstrated recent vertical 475 component inversion (from normal to reverse) along the left-lateral strike-slip Mondy fault 476 and along the north-Tunka fault (i.e; Larroque et al., 2001; Arjannikova et al. 2004; Ritz et al., 477 2018; Arzhannikov et al, 2018), this observation suggests that the Khamar-Daban Range and 478 the Tunka Basin are uplifting together. Inside the Tunka Basin, the uplift is observed within 479 the fluvial geomorphology, notably within the Bystraya river alluvial fan, in the eastern 480 termination of the basin, which shows an incision of $\sim 66 \mathrm{~m}$, and within the Neogene 481 sediments of the basin which show an incision of 110 m (Mats et al., 2002; Arzhannikov et 482 al, 2018). In the Tory depression, the Irkut River displays incised meanders with terrace 483 heights up to $100 \mathrm{~m}$ above the present river bed (Shchetnikov, 2017). In the western part of 484 the basin, the Irkut River terraces display a staircase morphology in the hanging wall of the 485 Mondy fault (i.e. the southern compartment of the Mondy fault) both into the fluvio-glacial 486 deposits and the bedrock, indicating the uplift of the Khamar-Daban block together with the 487 488
Mondy depression. These observations also suggest that the main regional structures controlling this uplift are the north-Tunka and Mondy faults.

From our analysis, there was no tectonic activity along the southern border of the Tunka Basin during the Holocene, and therefore this topographic border does not represent a major source of seismic hazard. On the other hand, the Mondy, north-Tunka and Sayan faults correspond to the main active faults westwards the Baikal Lake, and have produced destructive earthquakes with magnitude close or larger to 7 during the Holocene (Treskov and Florensov, 1952; McCalpin and Khromovskikh, 1995; Delouis et al., 2002; Chipizubov et al., 2003; Ritz et al., 2018). Those faults are those representing a strong seismic hazard for industries and cities (mainly Irkutsk) developed in this former periglacial area.

\section{Conclusion}


500 x $5 \mathrm{~km}$ and located in the westernmost Tunka Basin at the foothill of the Khamar-Daban 501 Range. The structures are developed in a Holocene soft-sedimentary formation of roughly 6 502 m-thick and mainly composed by sands and silts of fluvio-aeolian origin. Several 503 cryoturbation features and the known local climatic context attest to a periglacial environment 504 during the sedimentation.

505 The main structures we observed correspond to E-W striking elongated ridges of 506 several hundred meters long and few meters high. The trenches opened trough these ridges display folded, sometimes overturned, stratas, and several networks of reverse faults which preclude a pure aeolian origin related to transport by strong E-W wind within the Tunka corridor. Taking into account the 3D reconstitution of the folds and faults networks thanks to

510 several perpendicular trenches we show that these structures are soft deformations resulting 511 from the growing of thick ice lenses a few meters below the present-day surface. They do not 512 have a tectonic origin. All these observations combined with the absence of recent 513 morphotectonic indices along the Tunka-Kharmar-Daban boundary leads to the conclusion 514 that there is no evidence of tectonic activity along the south-Tunka Basin. The seismic hazard 515 of the western Baikal zone is therefore mainly linked to the activity of the 3 major faults: Sayan, north-Tunka and Mondy which are reactivated by the far-field India-Asia collision.

\section{Acknowledgments}

519 This study benefited of the financial supports from the French CNRS-INSU and the Institute 520 of the Earth Crust projects for the field campaigns carried out between 1999 and 2001. It also 521 benefited from the French National Platform LMC14 of the National Service of INSU 522 “ARTEMIS” for the radiocarbon dating. This study was also supported by Russian 523 Foundation for Basic Research and CNRS (PRC program, grants № 17-55-150002/PRC 
525 under the leadership of Artem Kozyrev; we thank him for the opportunity to study the sections and for fruitful discussions. Remote sensing analysis of morphotectonic features was done thanks to the TanDEM-X project DEM_GEOL1193. We thank Vladimir San’kov, Anna

Parfeevets and Marin Lebedeva for fruitful discussions and their help in the field in Kyren site. We thank two anonymous reviewers for their thorough reviews which helped to improve 530 the manuscript.

\section{References}

533 Allard, M., Caron, S, Bégin, Y., 1996. Climatic and ecological controls on ice segregation and thermokarst: the case history of a permafrost plateau in Northern Quebec. Permafrost and Periglacial Processes 7, 3, 207-27.

Alexeev, S., Alexeeva, L., Kononov, A., 2014. Cryogenic deformation structures in Late Cenozoic unconsolidated sediments of the Tunka depression in the Baikal Rift Zone // Permafrost and Periglacial Processes 25, 117-126.

\section{9}

Antoine, P., Rousseau, Moine, O., D.D. Kunesch, S., Hatté, C., Lang, A., Zöller, L., 2009. Evidence of rapid and cyclic eolian deposition during the Last Glacial in European loess series (Loess Events): The high-resolution records from Nussloch (Germany). Quaternary Science Reviews 28, 2955-2973.

Antoine, P., Lautridou, J.-P., Laurent, M., 2000. Long-Term Fluvial archives in NW France:

Arjannikova, A., Larroque, C., Ritz, J.-F., Déverchère, J., Stéphan, J.-F., Arjannikov, S., San'kov, V., 2004. Geometry and kinematics of recent deformation in the Mondy-Tunka area (south-westernmost Baikal Rift zone, Mongolia-Siberia). Terra Nova 16, 5, 265-272. 
Arzhannikov, S.G., Braucher, R., Jolivet, M., Arzhannikova, A.V., 2015. Late Pleistocene glaciations in southern East Sayan and detection of MIS 2 end moraines based on beryllium (10Be) dating of glacier complexes. Russian Geology and Geophysics 56, $1509-1521$.

Arzhannikov, S.G., Ivanov, A.V., Arzhannikova, A.V., Demonterova, E.I., Jansen, J.D., Preusser, F., Kamenetsky, V.S., Kamenetsky, M.B., 2018. Catastrophic events in the Quaternary out flow history of Lake Baikal. Earth-Science Reviews 177, 76-113.

Arzhannikova, A.V., Arzhannikov, S.G., Semenov, R.M., Chipizubov, A.V., 2005. Morphotectonics and Late Pleistocene - Holocene deformations in the Tunka system of basins (Baikal Rift, Siberia). Zeitschrift fur Geomorphologie 49, 4, 485-494.

Arzhannikova, A.V., Larroque, C., Arzhannikov, S.G., 2003. Holocene deformation in the western end of the Tunka system of rift basins (Southwestern Baikal Rift). Russian Geology and Geophysics 44, 4, 373-379.

Arzhannikova, A.V., Melnikova, V.I., Radziminovich, N.A., 2007. Late Quaternary and current deformation in the western Tunka system of basins: evidence from structural geomorphology and seismology. Russian Geology and Geophysics 48, 305-311.

Audemard, F.A., de Santis, F., 1991. Survey of liquefaction structures induced by recent moderate earthquakes. Bull. Int. Assoc. Eng. Geol. 44, 5-16.

Baize, S., Coulon, M., Hibsch, C., Cushing, M., Lemeille, F., Hamard, E., 2007. Non-tectonic deformation of Pleistocene sediments in the eastern Paris basin, France. Bull. Soc. Geol. Fr. 178, 5, 367-381.

Bridgland, D.R., Keen, D.H., Westaway, R., 2007. Global correlation of Late Cenozoic fluvial deposits: a synthesis of data from IGCP 449. Quaternary Science Reviews 26, 2694-2700. 
573 Chipizubov, A.V., 2017. Problematic historical earthquakes in the Baikal region. Seismic Instruments 53, 2, 155-172.

575 Chipizubov, A.V., Smekalin, O.P., Semenov, R.M., 2003. Fault scarps and prehistoric earthquakes in the Tunka fault (southwestern Baikal region). Russian Geology and Geophysics 44, 6, 561-574.

Delouis, B., Déverchère, J., Melnikova, V., Radziminovitch, N., Loncke, L., Larroque, C., J.F. Ritz, V. San'kov, 2002. A reappraisal of the source of the $1950(\mathrm{Mw}=6.9)$ Mondy earthquake, Siberia, and its relevance to the present-day strain pattern at the southwestern end of the Baikal rift zone. Terra Nova 14, 491-500.

Geological map 1:200 000, East Sayan series, sheet M-47-VI. Leningrad: VSEGEI, 1961.

583

584

585

586

Gladkov, A.S., Lunina, O.V., 2010. Seismites of the Southern East Siberia: research problems and perspectives. Geodynamics \& Tectonophysics 1, 3, 249-272 (in Russian).

Golenetsky, S.I., 1998. Seismicity of the region of the Tunka basin on the southwestrn flank of the Baikal Rift in the light of experimental observations carried out in the second half of the XX century. Russian Geology and Geophysics 39, 2, 260-270.

Groisman, P.Y., Blyakharchuk, T.A., Chernokulsky, A.V., Arzhanov, M.M., Marchesini, L.B., Bogdanova, E.G., Borzenkova, I.I., Bulygina, O.N., Karpenko, A.A., Karpenko, L.V., Knight, R.W., Khon, V.C., Korovin, G.N., Meshcherskaya, A.V., Mokhov, I.I., Parfenova, E.I., Razuvaev, V.N., Speranskaya, N.A., Tchebakova, N.M., Vygodskaya, N.N., 2013. Climate Changes in Siberia, In: Groisman, P., Gutman, G. (Eds.), Regional Environmental Changes in Siberia and Their Global Consequences. Springer Environmental Science and Engineering. Springer, Dordrecht, pp. 57-109.

Harris, S.A., 1993. Palsa-like mounds developed in a mineral substrate, Fox Lake, Yukon territory. Sixth international conference on permafrost. Proceedings. Beijing, China, Wushan Guangzhan, China: South China University of Technology Press, 1, 238-43. 
Jipa, D.C., 2014. The loess-like deposits in the Lower Danube basin. Genetic significance. Geo-Eco-Marina 20, 7-18.

Jolivet, M., Arzhannikov, S., Chauvet, A., Arzhannikova, A., Vassalo, R., Kulagina, N., Akulova, V., 2013. Accommodating large-scale intracontinental extension and compression in a single stress- field: a key example from the Baikal Rift system. Gondwana Research 24, 918 -935.

Khromovskikh, V.P., Solonenko, V.P., Gilkin, V.M., Golenetskiy, S.I., Kurushin, R.A., Misharina, L.A., Medvedeva, G.Ia., Solonenko, N.V., Shmotov, A.P., 1975. Seismotectonics and seismicity in the southeastern East Sayan. Novosibirsk, Nauka, 134 p. (in Russian).

Krivonogov, S.K., Safonova, I.Y., 2017. Basin structures and sediment accumulation in the Baikal Rift Zone: Implications for Cenozoic intracontinental processes in the Central Asian Orogenic Belt. Gondwana Research 47, 267-290.

Kondorskaya, N.V., Shebalin, N.V., 1977. A new catalog of strong earthquakes in the USSR from ancient times to 1975. Moscow, Nauka, 536 p. (in Russian).

Kozyrev, A., Shchetnikov, A., Klemenev, A., Filinov, I.A., Fedorenko, A., White, D., 2014. The early upper palaeolithic of the Tunka rift valley, lake Baikal region, Siberia. Quaternary International 348, 4-13.

Larroque, C., Ritz, J.F., Stéphan, J.F., San’kov, V., Arjannikova, A., Calais, E., Deverchère, J., Loncke, L., 2001. Interaction compression-extension à la limite Mongolie-Sibérie: analyse préliminaire des déformations récentes et actuelles dans le bassin de Tunka. C.R. Acad. Sci. Paris 332, 177-184.

Léger, M., 1990. Loess landforms. Quaternary International 7/8, 53-61.

Logatchev, N.A. (Ed.), 1974. Uplands of Cis-Baikal and Trans-Baikal. The History of the Surface Topography of Siberia and the Far East. Nauka, Moscow, 360 p. (in Russian). 
623 Logatchev, N.A., 2003. History and geodynamics of the Baikal Rift. Russian Geology and $624 \quad$ Geophysics 44, 5, 373-387.

625 Logatchev, N.A., Zorin, Y.A., 1987. Evidence and causes of the 2-stage development of the 626 Baikal Rift. Tectonophysics 143, 1-3, 225-234.

627 Lukina, N.V., 1989. Quaternary movements along the faults in the southwestern flank of the 628 Baikal Rift zone. Geotektonika, 2, 89-100 (in Russian).

629 Lounina, O.V., Gladkov, A.S., 2004. Fault structure of the Tunka rift as a reflection of 630 oblique extension. Dokl. Earth Sci. 398, 7, 928-930.

631 Mats, V.D., Fujii, S., Mashiko, K., Granina, L.Z., Osipov, E.Yu., Efimova, I.M., Klimanskii, A.V., 2002. Paleohydrology of Lake Baikal in relation to neotectonics. Russian Geology and Geophysics 43, 2, 142-154.

Mats, V.D., Ufimtsev, G.F., Mandelbaum, M.M., 2001. Cenozoic of the Baikal Rift basin: Structure and geological history. Novosibirsk, Geo, 252 p. (in Russian).

Mazilov, V.N., Kashik, S.A., Lomonosova, T.K., 1993. Oligocene deposits of the Tunka depression (Baikal Rift System), Russian Geology and Geophysics 34, 8, 68-73.

638 McCalpin, J.P., 1996. Paleoseismology. Academic Press, San Diego, 588 p.

639 McCalpin, J.P., Khromovskikh, V.S., 1995. Holocene paleoseismicity of the Tunka fault, $640 \quad$ Baikal Rift, Russia. Tectonics 14, 3, 594-605.

641 Melnikova, V.I., Radziminovich, N.A., 1998. Mechanisms of action of earthquake foci in the 642 Baikal region over the period 1991-1996. Russian Geology and Geophysics 39, 11, 643 1598-1607 (in Russian).

644 Moine, O., Antoine, P., Hatté, C., Landais, A., Mathieu, J., Prud’Homme, C., Rousseau, D.645 D., 2017. The impact of Last Glacial climate variability in west-European loess revealed 646 by radiocarbon dating of fossil earthworm granules. Proceedings of the National 
Academy of Sciences of the USA. Earth, Atmospheric, and Planetary Sciences, doi: 10.1073/pnas.1614751114.

649

650

651

652

653

654

655

656

657

658

659

660

661

662

663

664

665

666

667

668

669

670

671

Obermeier, S.F., Olson, S.M., Green, R.A., 2005. Field occurrences of liquefaction-induced features: a primer for engineering geologic analysis of paleoseismic shaking. Eng. Geol. 76, 209-234.

Olyunin, V.N., 1965. Neotectonics and glaciation of the Eastern Sayan. Moscow, Nauka, 126 p. (in Russian).

Parfeevets, A.V., San'kov, V.A., 2006. Geodynamic conditions of evolution of the Tunka branch in the Baikal Rift system. Geotectonics 5, 377-398.

Petit, C., Déverchère, J., 2006. Structure and evolution of the Baikal Rift: A synthesis. Geochemistry, Geophysics, Geosystems, 7, Q11016. DOI: 10.1029/2006GC001265

Petit, C., Fournier, M., 2005. Present-day velocity and stress fields of the Amurian Plate from thin-shell finite-element modelling. Geophysical Journal International 160, 1, 357-369.

Pissart, A., 2002. Palsas, lithalsas and remnants of these periglacial mounds. A progress report. Progress in Physical Geography 26, 4, 605-621.

Stuiver, M., Reimer, P.J., Reimer, R.W., 2019. CALIB 7.1 [WWWprogram]. http://calib.org, accessed 2019-1-28.

Radziminovich, N.A., Bayar G., Miroshnichenko A.I., Demberel S., Ulziibat M., Ganzorig D., Lukhnev A.V., 2016. Focal mechanisms of earthquakes and stress field of the crust in Mongolia and its surroundings. Geodynamics \& tectonophysics 7, 1, 23-38.

Radziminovich, N.A., Gileva, N.A., Melnikova, V.I., Ochkovskaya, M.G., 2013. Seismicity of the Baikal Rift system from regional network observations. Journal of Asian Earth Sciences 62, 146-161.

Radziminovich, Ya.B., Shchetnikov, A.A., 2005. A large earthquake of 8 March 1829 on the southwestern flank of the Baikal Rift system. Vulkanologiya i Seismologiya 3, 42-50. 
672 Radziminovich, Ya.B., Shchetnikov, A.A., 2013. Historical earthquakes studies in Eastern

673

674

675

676

677

678

679

680

681

682

683

684

685

686

687

688

689

690

691

692

693

694

695

696

Siberia: State-of-the-art and plans for future. Journal of Asian Earth Sciences 62, 134 145.

Ravsky, E.I., Alexandrova, L.P., Vangengeim, E.A., Gerbova, V.G., Golubeva, L.V., 1964. Antropogene deposits in the South of Eastern Siberia. Moscow, Nauka, 280 p.

Ritz, J-F., Larroque, C., Stephan, J-F., Sankov, V., Arjannikova, A., Calais, E., Deverchere, J., Loncke, L., 2000. When compression meets extension: interaction or competition? The example of the Tunka basin (West Baikal, Siberia). Geosciences 2000, Manchester, Avril 2000.

Ritz, J.-F., Arzhannikova, A., Vassallo, R., Arzhannikov, S., Larroque, C., Michelot, J.-L., Massault, M., 2018. Characterizing the present-day activity of the Tunka and Sayan faults within their relay zone (western Baikal Rift system, Russia). Tectonics 37, 5, 13761392.

San’kov, V., Miroshnichenko, A., Levi, K., Luknev, A., Melnikov, A., Delvaux, D., 1997. Cenozoic stress field evolution in the Baikal Rift zone. Bull. Centres Rech. Explor.-Prod. Elf-Aquitaine 21, 2, 435-455.

Shchetnikov, A., 2016. Morphotectonics of the Tunka rift and its bordering mountains in the Baikal Rift system, Russia. Geomorphology 273, 258-268.

Shchetnikov, A., 2017. Morphotectonic inversion in the Tunka rift basin (southwestern Baikal region). Russian Geology and Geophysics 58, 7, 778-786.

Shchetnikov, A.A., White, D., Filinov, I.A., Rutter, N., 2012. Late Quaternary geology of the Tunka rift basin (Lake Baikal region), Russia. Journal of Asian Earth Sciences 46, 195208.

Shchetnikov, A.A., Bezrukova, E.V., Matasova, G.G., Kazansky, A.Y., Ivanova, V.V., Danukalova, G.A., Filinov, I.A., Khenzykhenova, F.I., Osipova E.M., Berdnikova, N.E., 
Berdnikov I.M., Rogovskoi, E.O., Lipnina, E.A., Vorobyeva, G.A., 2019. Upper Paleolithic site Tuyana - a multi-proxy record of sedimentation and environmental history during the Late Pleistocene and Holocene in the Tunka rift valley, Baikal region. Quaternary International 543, 138-157.

Shebalin, N.V., Leydecker, G., 1997. Earthquake Catalogue for the Former Soviet Union and Borders up to 1988. Office for Official Publications of the European Communities, Luxembourg, 135 p.

Sherman, S.I., Medvedev, M.E., Ruzhich, V.V., Kiselev, A.I., Shmotov, A.P., 1973. Tectonics and volcanism of the southwestern Baikal Rift zone. Nauka, Novosibirsk, 135 p. (in Russian).

Smekalin, O.P., 2008. A study of paleoseismogenic deformations in South Pribaikalye. IPE RAS, Moscow, 101 p. (in Russian).

Smekalin, O.P., Shchetnikov, A.A., White, D., 2013. Arshan palaeoseismic feature of the Tunka fault (Baikal Rift zone, Russia). Journal of Asian Earth Sciences 62, 317-328.

Solonenko, A., Solonenko, N., Melnikova, V., Shteiman, E., 1997. The seismicity and earthquake focal mechanisms of the Baikal Rift Zone. Bulletin - Centres de Recherches Exploration-Production Elf- Aquitaine 21, 1, 207-231.

Stuiver, M., Reimer, P.J., Reimer, R.W., 2019, CALIB 7.1 [WWW program] at http://calib.org.

Van Vliet-Lanoe, B., Magyari, A., Meilliez, F., 2004. Distinguishing between tectonic and periglacial deformations of quaternary continental deposits in Europe. Global and Planetary Change, 43, 103-127.

Veldkamp, A., Van Dijke, J.J., 2000. Simulating internal and external controls on fluvial terrace stratigraphy: a qualitative comparison with the Maas record. Geomorphology 33, 225-236. 
Wolfe, S.A., Stevens, C.W, Gaanderse, A.J., Oldenborger, G.A., 2014. Lithalsa distribution, morphology and landscape associations in the Great Slave Lowland, Northwest Territories, Canada. Geomorphology 204, 302-313.

\section{Figures captions:}

Figure 1. (a) Landsat image LT513502 of the Tunka basin with microseismicity (1960-2018, magnitude 2-6, catalogue of the regional seismological network, Baikal Division of Geophysic Survey of the Siberian Branch of the RAS, Irkutsk). Pink circles : historical earthquakes : 1742 ( $\mathrm{I}=$ VII, estimated magnitude 7.5), 1814 ( $\mathrm{I}=\mathrm{V}$, estimated magnitude 6.4), 1829 (estimated magnitude 7), 1950 (Mw 6.9), from Shebalin and Leydecker, 1997; Radziminovich and Shchetnikov, 2005; 2013; Chipzubov, 2017; Delouis et al., 2002. Focal mechanisms in the south Tunka basin are from Delouis et al. (2002). (b) Digital elevation model of the Tunka Basin with main active faults and their kinematics (1-normal, 2-reverse, 3-strike-slip): TF - Tunka fault, MSF - Main Sayan Fault, MF - Mondy Fault, “STF ?” assumed South Tunka Fault.

Figure 2. (a) Google earth satellite image (Landsat) of the Kyren area within the southern central part of the Tunka Basin. (b) Morphological interpretation: 1 Holocene alluvial deposits, 2 Upper Pleistocene sand deposits, 3 Upper Pleistocene fluvio-glacial deposits, 4 Holocene alluvial fans, 5 Rivers, 6 Former meanders of the Irkut River, 7 Lakes, 8 Ridges, 9 River terraces, 10 Morphological scarps. (c) 3D view of the Haragun alluvial fan. (d) Topographic profiles (after TanDEM-X DEM, $12 \mathrm{~m}$ resolution); the dashed-line defines the ground surface, while the high frequency low amplitude signal observed above it corresponds to vegetation (trees between 5 and $15 \mathrm{~m}$ high). 
747 Figure 3. Aerial picture (a) and Google Earth satellite image (Digital Globe) (b) of the site 748 studied to the south of Kyren village. Red arrows show dominant wind directions. Location of 749 the 3 trenches opened: trench $1\left(51^{\circ} 39,803^{\prime} \mathrm{N} ; 102^{\circ} 08,086^{\prime} \mathrm{E}\right)$, trench $2\left(51^{\circ} 39,662^{\prime} \mathrm{N}\right.$; 750 $\left.102^{\circ} 08,579^{\prime} \mathrm{E}\right)$, trench $3\left(51^{\circ} 39,653^{\prime} \mathrm{N} ; 102^{\circ} 08,517^{\prime} \mathrm{E}\right)$.

751

752 Figure 4. Algak river bank section: (a) Field picture of the river bank section. (b)

753 Stratigraphic description: 1) Dark grey-brown humic topsoil horizon. 2) Grey-brownish silty 754 sands with numerous root tracks. 3) Little dark grey-brown sandy humic horizon; 4) Greyish 755 homogeneous silty sands showing a strongly deformed lower boundary with unit 6 756 (downward protrusion features / load casting) and deformed "balls" from organic unit 6. 5) 757 Strongly deformed sandy silt beds and dark grey-brown organic (peaty) horizon (main 758 cryoturbation horizon). 6) Homogeneous light-grey sandy silts with deformed upper boundary 759 (upward protrusion). 7) Light-grey sandy silts with horizontal wavy stratification (fluvio760 aeolian). 8) Light-grey sandy fluvial silts with mainly planar stratification, locally cross761 bedded (fluvial to fluvio-aeolian). 9) Silto-organic grey-brown horizon (alluvial meadow 762 soil). 10) Yellowish-grey loamy-sands with some organic debris underlying the stratification 763 and little frost-wedges. 11) Peaty horizon with large wood remains / tree stump in situ). 12) 764 Laminated light brownish-grey silts with thin (millimetric) organic debris layers. 13) Peaty 765 horizon with wood remains. 14) Laminated yellowish-grey silt with thin (millimetric) organic 766 debris layers. 15) Yellowish-grey sandy silt with numerous organic debris and involutions 767 (small scale periglacial deformations). 16) Grey-green laminated sandy loam with fine 768 organic layers and some scattered wood remains. 17) Brownish peaty horizon (lower 769 boundary not observed). 
771 Figure 5. Field pictures of the morphological features analysed within the Kyren site where

772 we opened the trenches: (a) Southwestern view of a break of slope (indicated by yellow

773 triangles) at the western tip of the E-W linear feature observed in the aerial picture; (b) and (c)

774 Northeastern and southwestern views of the aligned domes structures (indicated by red

775 triangles), respectively.

776

777 Figure 6. Trench 1 (a) log of the western wall: 1 Dark brown modern soil, 2 Light grey 778 stratified silty-loess units, 3 Beige finely stratified silty units with oxidation marks, 4

779

780

781

782

783

784

785

786

787

788

789

790

791

792

793

794

795

Figure 7. Trench 2 (a) Log of the western wall (the northern part of the trench is the eastern wall that had been turned to appears as the continuity of log): 1 Dark brown modern humic soil, 2 Silty light brown reddish palaeosol, 3 Homogenous grey-bluish fine silty-loess unit, 4 Finely stratified silty-clayey unit, 5 Silty unit with fine clayey-silty interstratifications, 6 Clayey-silty triangular unit (ice wedge), 7 Palaeosol affected by solifluction, 8 Fractures, 9 Location and age of collected samples. (b) Northwestern view of the southern part of the trench, (b) Southwestern detailed view of a reverse fault, (c) Western view of the sampled palaeosol within the northwards overturned units in the northern part of the trench.

Figure 8. Trench 3 (a) Log of the eastern wall: 1 Dark brown upper horizon of modern soil, 2 Light brown silty lower horizon of modern soil, 3-6 - light to dark grey stratified silty - loessy units with oxidations marks and clay-rich lower parts, 7 Small humic soil horizon affected by solifluction, 8 Fractures. (b) Photo mosaic of the eastern wall. 
797 Figure 9. (a) Stratigraphic profile of trench 3b: 1 - Dark brown-grey humic sandy silt (Ah 798 upper horizon of the topsoil). 2- Dark brown sandy silt with granular structure and numerous 799 root tracks (lower horizon of the topsoil). 3 - Grey-brown sandy loess with numerous 800 bioturbations (root tracks). 4- Greyish sandy loess including numerous blocks of reworked 801 organic silt (infilling of a little thaw channel). The very sharp, angular and strongly erosive 802 boundary between 4 and 5 is typical for thermokarst erosion processes. 5 - Sequence of grey803 brown sandy loess, locally finely laminated and including little frost-cracks (cryo804 desiccation). The laminations and the frost-cracks are clearly underlined by thin sand beds $(\approx$ $8051 \mathrm{~mm}$ ). 6 - Greyish, compact sandy loess, with numerous oxidised orange patches and bands 806 iron oxide), and ferro-manganic nodules (0,5 to 1mm) (tundra gley horizon). 7 - Greyish, 807 sandy loess, lightly coarser than 5, with some orange iron oxide patches (deep horizon of 808 tundra gley 5). (b) 3D-view of the deformations observed at the junction between profiles of 809 trenches 3 and 3b.

810

811 Figure 10. (a) Google Earth satellite image (Landsat) of the Tuyana studied area within the 812 easternmost extremity of the Tunka depression. (b) Morphological interpretation: 1 Holocene 813 alluvial deposits, 2 Upper Pleistocene sand deposits, 3 Upper Pleistocene fluvio-glacial 814 deposits, 4 Rivers, 5 Ancient meanders of the Irkut River, 8 Ridges.

816 Figure 11. (a) Digital Elevation Model (TanDEM-X, contour lines every $5 \mathrm{~m}$ ) of the foothills 817 of the Khamar-Daban Range, where the Irkut River incises the Elovsky Spur; (b) Enlargement 818 of the studied area; the black dashed rectangle corresponds to the Tuyana archaeological site. 819 (c) Southern view of the Tuyana archaeological site. 
821 Figure 12. Examples of cryogenic deformations in the late Pleistocene-Holocene deposits of 822 the archaeological site of Tuyana (see the position of sections within Figure 11b).

823

824 Figure 13. Examples of gravitational deformations in the Tuyana archaeological site area. (a)

825 digital elevation model with landslide location. (b,c) cross sections of the Late Pleistocene 826 deposits deformed by slope masse movements (see the position of sections within Figure 827 11b). The yellow dashed lines show the zone of unconformity formed as a result of erosion in 828 the Younger Dryas (Shchetnikov et al., 2019). Radiocarbon ages according to (Shchetnikov et 829 al., 2019). (d) photo of the surface of the landslide.

830

831 Figure 14. Eastern view of 6 consecutive N-S sections (a-f) of the Tuyana archaeological site 832 (see the position of sections within Figure 11b).

833

834 Table 1. Radiocarbon $\left({ }^{14} \mathrm{C}\right.$ BP) and calibrated ages (calBP) from Kyren profiles.

835 Dendrochronologically calibrated calendar age ranges were calculated using the program 836 Calib 7.1 Radiocarbon Calibration (Stuiver et al., 2019) with 2 standard deviations 837 uncertainty. The age ranges are rounded off to the nearest decade. 